\title{
Didactic Innovation in Science Teaching: A Qualitative Study on the Framing of an Educational Museum in a Brazilian Public State High School
}

\author{
Guy Barros Barcellos \\ Programa de \\ Pós-GraduaçãoemEducaçãoemCiên \\ cias e Matemática-PUCRS, Porto \\ Alegre (RS), Brazil; \\ Basic Education Direction of \\ Aelbra, Canoas (RS), Brazil
}

\author{
Ricardo Willian Da Costa \\ Assumpção \\ Colégio Ulbra São Mateus, \\ Cachoeirinha (RS), Brazil
}

\author{
Carin Cristina Borkert \\ Kuchenbecker, \\ Núrfis dos Santos Vargas \\ Basic Education Direction of Aelbra, \\ Canoas (RS), Brazil
}

\begin{abstract}
In this article, we describe and analyze the framing of a science educational museum in a state school in the municipality of Porto Alegre (Brazil) and the impacts of it on the teaching and learning processes taking place there. As tools to data setting we utilized dialogues with the participant teacher and observed the practices being developed. We realized, during the course of the project, that the framing the museum by students research breaks with school's organizational invariants, allowing the emergence of a teaching style adapted to the specificities of each individual and an environment in which their interests are transformed into scientific quests and problems that lead to research projects capable to signify the scientific knowledge as a way to empowerment.
\end{abstract}

Keywords: science teaching, teaching innovation, educational museum

\section{Introduction}

This paper presents a qualitative research on the process of installing an educational museum of natural sciences at a public high school, located in the city of Porto Alegre (Brazil). We analyze how such a project becomes a didactic innovation once it breaks with a logocentric perspective and with organizational invariants of common sense that have been established as the school curriculum (Canário, 2006).

We start from the assumption that innovating and modifying the areas of school education becomes a contemporary need, as the school is a space occupied by multiple subjects and, consequently, a multitude of cultures, beliefs, and life stories. Recognizing these pluralities becomes a primordial concern of the current

Guy Barros Barcellos, M.Sc. in Science and Math Education, Ph.D. candidate in Science and Math Education (Programa de Pós-Graduação em Educação em Ciências e Matemática da Pontifícia Universidade do Rio Grande do Sul-PUCRS) and Pedagogical Coordinator of Basic Education Direction of Aelbra (Lutheran Educational Association of Brazil).

Ricardo Willian Da Costa Assumpção, high school student of Colégio ULBRA São Mateus (Lutheran University of Brazil).

Carin Cristina Borkert Kuchenbecker, pedagogue and specialist in Psychopedagogy and Project; assessor of the of Basic Education Direction of Aelbra (Lutheran Educational Association of Brazil).

Núrfis dos Santos Vargas, pedagogue and specialist in Development of Educational Social Projects; specialist in Educational Supervision and General Director of Basic Education Direction of Aelbra (Lutheran Educational Association of Brazil). 
education and an ethical dimension of pedagogical "praxis". It becomes an important task, then, for the teacher to break with the very historical matrix of school, since the modern school was founded in homogeneity of logic which sought to nullify the specificities and political peculiarities, social and cultural peculiarities (Canário, 2006). Thus, a change is necessary on the practices and theoretical frameworks under which many educational choices are built on and which show an assumption that the teacher's knowledge is greater than or truer than the knowledge of the students.

With Freire's (1981; 2011) theories, such assumptions became unsustainable, given the impossibility of establishing an axiological hierarchy between the different ways of conceiving reality and the conception of the ranking of the different ways of seeing the world. Thus, the effort to overcome the learner's "wrong views" would lead to a dehumanization of the individual. The "freirean" ideas continue to be of great importance to the contemporary theories of education, being the founding blocks of a theoretical perspective that aims to disrupt with "logocentrism" and "adult centrism," which are still hegemonic in many curricular practices.

In this sense, the practice narrated and analyzed in the course of this study proposes a rupture in the existing asymmetry between the teacher and the students, through the implementation of a new learning site at school. This space, instead of being governed by a chronometer and the homogeneous distribution of students in space, is marked by an affective relationship and an an learning experience of "kairos" time, i.e., the singular time of each individual.

In the first section, entitled "Didactic Innovation in the Contemporary Context," the authors seek to conceptualize what is didactic and its relationship with the school curriculum. Since the focus of this research comprises science education in the contemporary world, the second section of our article is named "Dogmatism and Science Teaching." This section presents some theoretical lines that show that teachers' practices are associated with the conceptions of scientific knowledge they possess, and the relativity of this form of knowledge provided by the epistemology of science have a direct impact on the practices developed in the classroom. The third section of the study presents the methodology and the instruments used for data generation and analysis procedures of the "corpus" of the research.

The section "The Framing of an Educational Museum: Teaching Innovation" contextualizes the project being developed, showing how it broke with certain historical matrix in which the school is based. The text concludes by discussing the importance of the emergence of similar projects that give the opportunity for a rupture with changeless educational practices.

\section{Didactic Innovation in a Contemporary Context}

Even among researchers who go deep into the subject, there does not seems to be a consensus on the meaning of the concept of "didactic." However, there is a convergence in acknowledging that it is due to Comenius, and his work Didactica Magna (Comenius, 2002), the role of being the founder of what we mean today by didactics. Another covenant among the authors that address this theme, according to Ohlweiler (2012), is the existence of an intrinsic relationship between didactics and curriculum.

In turn, Moreira (1998, p. 38) stated that it is common to accept that "the curriculum turns predominantly to issues related to the selection and organization of school knowledge, while teaching prioritizes education as their object of study." In this theoretical perspective, it would be accepted that didactics are a set of techniques, procedures, and strategies aimed at answering the question: How to teach? While the curriculum, in a critical perspective, consists of the content that will make up the "curricula" of an institution, and the ways in which 
that institution deals with the time and space of education. Didactic would be understood, therefore, as a dimension of the curriculum, once the choices and techniques employed by teachers are dependent on the selected content to be taught, and above all, of the time and spaces determined for teaching.

In this understanding, an educational change can depend on acurriculum transformation. That said, it is presumes the existence of such a distinction between didactic and curriculum. Nevertheless, it is assumed that it is not only the curriculum that determines the educational choices, but that the reverse process may occur, when choosing certain teaching techniques and procedures, the teacher may foment a change in the curriculum of the institution in which it operates.

It is pivotal to this research not only trying to answer "How to teach?”, but to demonstrate some skills that it covers. The field of studies that didactics would cover involves the teaching techniques and strategies, having as a common concern of curriculum studies the thought of "the process of producing school knowledge, teacher training and school culture” (Moreira, 1998, p. 39).

In this context, thinking over of didactic innovations may imply considering and questioning the curriculum itself that is present in schools. Even if one only modifies the practical teaching techniques or strategies, its effectiveness will result in changes in time, space, forms of evaluation, and the selected content of the curriculum of educational institutions.

Even if the teacher's action is only associated with the realization of educational choices, notwithstanding teaching dynamic does not involve only thinking on the teaching process that occurs in the classroom (Carvalho, 2009). The teacher needs to become involved in the discussion of the science teaching and curriculum, since the contents that compose it unveil the school's philosophy and goals. In this view, there is no clear distinction or complete dissociation between both areas, as they converge and interrelate.

Having previously considered a definition of didactic, curriculum and the intrinsic relations between both fields of study showed up, it is proposed analyzing the contemporary necessity for didactic innovation. Ohlweiler (2012, p. 75) stated that only from the 1990s on have certain teaching practices been developed that were more "contextualized and concerned with the teaching and learning process in a plural sense," breaking with the predominant technicistic tradition in education from the period the Brazilian military dictatorship (1964-1984), despite modern education in Brazil still carry traces of this technicism. However, it is necessary to recognize that there are no ruptures in the developed practices and we can still find pedagogies in schools based on training and memorizing, displaying a conception of students as receptacles of a pre-selected set of information. In this set of pedagogies that Freire (2011) characterized these as "bank pedagogy,” the teacher-a person who knows the reality—narrates it to and lectures the students about it. It is, thus, established pedagogy based on the monologue and "professorial" classes. Freire (2011, p. 67), upon writing criticism of these pedagogies, stated that:

The rote memorizing of the object's profile is not true learning of the object nor the content. In this case, the student works more as a passive subject of transfer of the object or content than as a critical subject, epistemologically curious, who builds the knowledge of the object or takes part in its construction.

The subject becomes, through the technicistic philosophy, a subject devoided of critical thinking. Thus, an environment lacking in meaning, becomes the main variable that allows the spread of a pathology known as mental alienation. (Vygotsky, 1987)

In a critical approach to pedagogy, it is started from the assumption that the subjects themselves build interpretations and theories about the reality that surrounds them and take them as true (Berger \& Luckmann, 
1985). However, often the interpretations that an individual produces about his reality are based on magical fundaments and animistic thoughts that do not allow them protagonist action in the world (Freire, 1981). It becomes the job of education to aid in overcoming this obstacles, causing the individual the skill to exercise a critical and reflexive action about his ways of thinking and the reality in which one lives.

The pedagogy proposed by Freire $(1981 ; 2011)$ aims to break with the hierarchy of the different ways of conceiving reality, valuing the student's knowledge of the world, replacing a traditional pedagogy-that emphasized the development of memory based, trans missive and preparatory learning towards a dialogical and responsive pedagogy.

If in certain historical moments, the "banking pedagogy" was accepted and became operational for working with a homogeneous group of students, after the promulgation of the Brazilian Constitution and Law of Directives and Bases of National Education (Brazil, 1996; 2009) those grounds fell apart. That happened because democratizing access to education and creating strategies to ensure the permanence of students in basic education makes the school spaces be occupied by a diversity of cultures and beliefs. Faced with this, Delizoicov et al. (2011, p. 33) pointed out that this new reality "cannot be addressed with the same teaching practices of earlier decades or of the school of a few and for few." The didactic innovation arises as a contemporary necessity to discuss and strategize on how-to-work with multiple singularities that came to inhabit the school grounds.

In addition, one must realize that the school organization is a modern institution prototype-involved in establishing a particular social project—and practices that still occur inside this institution are largely based on Comenius' writing from the 17th century, especially in Didactica Magna (Comenius, 2002). At this angle, Canário (2006) stated that the school is an institution that retains a historical matrix and certain social practices since its foundation. The social, historical, and cultural context in which Comenius wrote his work was transformed and deeply altered just as our relationship with knowledge (Serres, 2013).

There is a consensus among authors, such as Canário (2006) and Santos (2013), despite studying different areas, that it is necessary to reinvent our ways of life and the institutions that characterize society. It is understood that the need to seek other ways of education that break with the perspective of a school based on the transmission of information (logocentrism), and above all, in a classroom in which there is a predominance of "master classes" and non dialogical lectures, in which the student is only seen as a vase empty of information. The next section of the study addresses the science teaching, showing how some didactic choices science teachers make offer a blurred image and even epistemologically insufficient of scientific knowledge to their students.

\section{Dogmatism and Science Teaching}

The pedagogical practices developed by teachers are intrinsically associated with the epistemological conceptions of scientific knowledge that teachers have (Borges, 1996; Gil Pérez, 2001; Fernandez et al., 2002). This section presents an etude about the relationship between pedagogical practices in science education and conceptions of scientific knowledge.

According to Vygotsky (1984), the construction of knowledge is a dynamics, which happens through the interaction of essential elements: the student, the content, the meaning, and the teacher, to whom goes the role of mediator.

In the empirical-positivist epistemology of scientific knowledge, science is seen as a set of information derived through the application of an unfolded method of "Cartesian" and "Baconian" theories. Scientific 
knowledge seen as linear and cumulative, where errors, doubt and subjectivity are supposed to be "exorcised" through the application of a series of previously written procedures. Scientific knowledge, in the empirical-positivist conception, is regarded as regal knowledge against other theories (common sense, religious knowledge, and metaphysical and philosophical theories), and this position is guaranteed by its alleged objectivity.

This view of science as knowledge that is at the top of an axiological hierarchy is being questioned and deconstructed with the works of philosophers, such as Karl Popper (1972), Thomas Kuhn (2001), Norwood Hanson (1975), and Gaston Bachelard (1996). The first criticism to the empirical-positivist conception is credited to Popper (1972), having stemmed from a positivist stance by pointing out that the progress of science occurs through a principle of refutation. Meaning that the scientist's effort is to refute practical experiences formulated previously.

Epistemologists, even those from different theoretical positions, show science as a human and historical production (Chassot, 2004; 2014). Therefore, science is not "transcendental," and its methods and procedures are human conventions in pursuit of observation and objective analysis of the environment (Chalmers, 1994). In this sense, Granger (1994, p. 113) said that science "is not your absolute certainty [...] our scientific knowledge is necessarily partial and relative.” The partiality and relativity of scientific knowledge, in turn, remains absent from science syllabuses (Pretto, 1995). Borda (1984) stated that:

Everyone knows that science is constructed by applying rules, methods, and techniques subject to a certain kind of rationality conventionally accepted by a small incorporated community of people called scientists, that for being human, are, therefore, subject to motivations, interests, beliefs and superstitions, emotions, and interpretations of their social, cultural, and individual development. (p. 44)

Science education is often associated with the transmission of information which, being labeled as scientific, is seen as true and indisputable, that is, pure knowledge and ahistorical. Thus, there is a dogmatic education based on the transmission of truth produced by experts and contained in textbooks or in specialized media information.

Connected to Vygotsky's conception regarding the intellectual structure, Novak (1981) added two more elements in this dynamics: context and evaluations. According to his hypothesis, the affective experience is positive and adds knowledge when the learner acquires achievements in understanding, being also a product of the exchange of meanings and feelings between teachers and students. Pretto (1995) emphasized that it is common to find in textbooks for the teaching of science a reproduction of "an authoritarian practice of those who know regarding those who know nothing” (p. 57).

In turn, Chassot (2014, p. 31) pointed out that the science teachers have the "greatest responsibility [...] seeking to help students become, with the teaching offered, into men and women who are critical citizens." The teaching of scientific truths through a monologue does not guarantee the capacity for criticism and awareness of the subject, in as much as this process dehumanizes the students, imposing in its core a feeling of powerlessness in the face social oppressions (Freire, 1981; 2011). Pursuant to Freire's thoughts, it is assumed that not only a subject who may take the position of oppressor, since this function can be performed by a certain piece of knowledge that is considered superior to that produced by the subjects of a lower layer of the population.

In the presented perspective, didactic innovation is a list of practices that aim to deconstruct the practices of transmission of information (logocentrism), as if that were enough to ensure learning. It also forms 
opposition to a stance that aims to teach science as asterile knowledge, higher than that produced by the subjects of a particular community. An innovative didactic would break with the teaching of science based on the lecture only, the same way it would overcome a false expecting them to givethe "right answers." Innovative practices for the teaching of science would require dialogue between teacher and student to be understood as a relationship that "is nourished by love and understanding. Therefore, only dialogue communicates. And when the two poles of the dialogue connect, with love, with hope, and with faith in each other, they become critical in the search for something" (Freire, 1981, p. 107).

\section{Methods}

The study is based on a qualitative approach, which for Biklen and Bogdan (1994) consists of a series of methods and techniques that work with data held in a descriptive way. The qualitative researchaims to provide a new understanding of reality, not with the objective of establishing a judgment of value or a generalization, but addressing to complex and extensive comprehensions about data.

Once, the descriptive material is the raw matter for qualitative research, the researcher becomes the main instrument for generating information when immersed in the environment that is being investigated (Biklen \& Bogdan, 1994). For this paper, the authors observed biology classes and "Research Seminars"” developed by a high school teacher, in a public state school. According to Tardif (2012), the action of observing practices that teachers develop allows one to identify certain hidden knowledgeswhen they verbalize it.

To complement the "corpus" of the research the authors developed written bibliographical studies created by the individual participating in the research and an interview was held with the teacher in order to clarify latent aspects in their practice. The datasetis presented introducing the developed practice, promoting interfaces with existing theories on the subject.

\section{The Framing of an Educational Museum: Teaching Innovation}

The scientific knowledge, the views of teachers and, consequently, the practices developed by them are closely associated with the graduation processes of these professionals (Tardif, 2012). However, when it comes to vocational training, it is not restricted only to undergraduate or graduate courses attended, but also to the period in which the teacher went to school as a student, which Tardif (2012) referred to as pre-professional training. In going to school as a student, the future teacher takes on a number of assumptions about the educational common sense (Gauthier, 2013) taking them to be truths. Tardif (2012) shown that even in college courses, many of these preconceptions are not deconstructed. It is believed that by making the professional make a genealogy of their education and autobiographical writing, they have the opportunity to experience a powerful moment, which entails the gathering of elements or brief notes, related and justifying the actions and practices developed by them.

Upon starting the present research, it is presented a brief biography of the teacher involved in this research, with the excerpts below having been obtained by an interview, as well as reading his master degree thesis. "The role a educational museum installed by middle-school students in scientific literacy,” scrutinizes significant events for his professional training. The research participant teacher points out that:

The idea of the school museum was not an epiphany. It solidified in my mind due many years without realizing its

${ }^{1}$ A curricular subject established by the public education system of the state, with three hours per week. 
importance in my personal and professional life. It was a process of awareness, very slow and subtle. Not long ago, I was finally able to understand it. It is impossible to explain it is maieutic without revisiting my earliest childhood.

The teacher emphasized that the first museum he installed was a small model with dinosaur miniature he set up at five years old and called it a "museum." For him, his "attraction to museums emerged from my experiences, very emotional, in the museum where my father was the director" (Interview). In his master thesis pointed out that:

On the cold and rainy days of late winter, I explored the mollusks drawers of the the large malacological collection. Each drawer, which opened at random, held a new world of biodiversity. From the most microscopic "Caelatura" to the heaviest "Voluta" (mollusk scientific names), all were interesting. The single drawer that I knew exactly where it was and what it contained was that of the "Cypraea" genre of mollusks: oval shells, colorful and with porcelain look. All properly stored in boxes of paper and carefully cataloged by the researchers. I also remember the joy I felt when I found some shell lost in the sediment I observed in the stereoscopic microscope, an activity, proposed by my father, absorbed and fascinated me.

Even attending the oceanographic museum and having the chance to always be there and explore it freely, the participant teacher highlighted his feeling that this was "his father's" museum, the "great museum." "I was not great. It was small. I needed my own museum, a small one, like me. [...] And, I did not have one. It was not its creator.” The annoyance brought on by that feeling, made the teacher give continuity the model that he had started when he was five:

I collected "samples" of fish, crustaceans, mollusks, leaves, fossils, feathers, and stones. Everything that I considered curious or interesting, I would take to what I have called the "Museu da Natureza.” I was 9 or 10 and began to invite friends to be "curators.” The museum had already taken over my room. I held exhibition openings; temporary exhibitions (drawings and sculptures by myself and my friends), cultural gatherings (We sang and danced with Mozart's music in my father's vinyl player) and we took care of the aquariums with fishes and frogs.

When he attended high school, the teacher told how and why he proposed a museum project, that began to be combined with an educational purpose, when a teacher of his:

[...] Remembered that I had had a museum at home. She asked me to bring a few items of the collection to exhibit at the school cultural festival. I did so. I took fossils and mollusks and taught about each one. I felt very gratified in explaining them to the visitors. I enjoyed teaching. Behold, a second teacher, seeing my enthusiasm, suggested I do a project to set up the collection permanently at school. I cherished the idea and began to develop a project that I presented to the school principal.

From that moment on, the project turned to be a permanent exhibition in the school, where the teacher was involved, even after graduating and starting his research activities, being involved in molecular biology. The resumption of the museum project happened when writing an article to the book Contributions of an Interactive Museum to Education in Sciences and Mathematics (Borges et al., 2009). While working as a teacher in a private school in the metropolitan region of Porto Alegre (Brazil), the teacher developed a research action about his students installing a educational museum.

Upon analyzing his autobiography and the interface with installing a educational museum, the teacher said that this "is a completely empirical proposal. I am teaching as I learned. It is much more intuitive than it looks" (Interview). We can see that the project developed by the teacher and his life story are intertwined, and there are passages in the teacher's life that justify the methodological choices adopted by him in his classes. 
It is noteworthy that in the project described and reported below, the design of a museum is understood not only as a formal space for the construction of knowledge, nor just a place where collections are exhibited passively. The developed proposition for a museum comprises an existing educational space inside the school, where the teaching process is permeated by an affective relationship and horizontal "praxis" between teacher and student. Students have become curators, researchers and involved in the installation of the objects that made up the learning environment. It was during this process that their learning was built.

It is observed that the framing of the "Museum of Science and Consciousness"2 began with dialogical lectures in which the teacher told the history of humankind and science, as well as important aspects of building knowledge. Through these classes, the teacher presented to students how at different times in human history there were different relationships with the scientific knowledge.

Therefore, it is pointed that the lecture of the history of science does not consist in the methodological approach used, but rather a primary strategy used by the teacher in order to achieve specific objectives in the educational process - only a short stage of the process. Ergo, the professorial class is not condemned in the aforementioned teaching proposal, it becomes a specific strategy employed with specific goals, it simply loses its role as a central tool. In these practices, which narrated the relationship man-knowledge throughout history, the teacher did not adopt the posture of being a revealer of the absolute truth, but a mediator of the unstable and limited knowledge that humankind has of itself and the of the nature. Hence, the view of history as an absolute truth is relativized and problematized.

As for the importance of the history of science, for biology classes or other natural sciences, Bizzo (2013) emphasized that it is the history of science that allows students to understand that knowledge evolves, that is not a simple accumulation of truths. The history of science demystifies the empiricist conception of science as an absolute truth and universal knowledge, allowing students to understand the nature of scientific knowledge. For this to occur, according to Astolfi and Delevay (2005), it is relevant to preclude the idea that teaching the history of scientific knowledge is to allow students to know the biography of some great scientists. It is, first and foremost, to provide materials for the students, so that they can understand how, in certain contexts and historical moments, humans related to scientific knowledge.

The link between history of science and the perception that students have of the reality in which they live is what made emerge research topics of interest. From this, the teacher's work turns to develop a pedagogical process with their students (Freire, 2011), adopting a dialogic pedagogy and an investigative approach to school curriculum. In this matter, it is appropriate to present the concept that the participating teacher has on learning:

The human mind is an "island of Avalon," surrounded by eternal mists. We can make inferences, analogies, approximations, assumptions, and speculations, but we will never fully understand how the learning phenomenon occurs. A student, neurologically, learns like any human being and like any mammal. At the same time, each individual learns differently every minute. One never learn in the same way. The learning is a "kaleidoscope.” The author believes that the student learns by fascination, interest, creating and building, questioning and reformulating, cluttering, and reorganizing. One may learn through positive or negative emotions. Life is responsible for teaching with unpleasant emotions; the school must or should take charge of the opposite. To promote learning in the most pleasant and positive way possible. The more pleasure the student feels in learning, the more they will want to learn. The more you learn, the more you realize your ignorance and the more you will want to extinguish it. [...] A student learns with their thirst, with an intellectual "libido". If it is not pleasurable, it is not learning, it is stocking. And as we know, stocks run out. (Interview)

\footnotetext{
${ }^{2}$ Name given to the educational museum concerning this research. Installed by the teacher and his high school students of a public state school.
} 
In this excerpt, it is seen that the value and the emphasis that the teacher gives to "pleasure" in learning, in which the pleasure for the learner was to find a solution to a cognitive problem that affects her or him. The epistemic curiosities that students present are variable and are subject to a number of conditions, among which is the issue of their reality or problems of cognitive order. Contemporaneously, the theories of the psychological field, in particular the "multiple intelligences" (Gardner, 2003), indicated that the motivation to learn can also be related to the intelligences that students possess.

Furthermore, after Philippe Perrenoud (2000), it is understood that people develop certain skills that emerge when the didactic proposal is put into practice.

Coordinating and managing learning situations. As it is a museum curated by students, working from the representations of the subject and involving the same in research activities and projects, this is indispensable.

Administering the progression of learning. Managing the progression of learning in a museum built by students, for students, is a necessary action of the teacher acting as an advisor, so he or she may assess and collaborate on decisions and intervene in the freedom and creativity of the students when necessary, respecting and valuing singularities.

Creating and utilizing differentiation devices. Managing the ethnic and cultural diversity of a team of student-curators allows you to create an environment rich in meanings, where cooperation is seen during the execution of projects and presentations.

Including students in their own learning and their work. In the school, curating is not the students' only activity, they can actively participate in the planning and discussions to solve problems. Thus, the student has the opportunity to be a protagonist, constructing meanings from the activities of their personal project, generated from the range of activities offered by the teacher.

Team working. Team work is the main foundation of this didactic, where it is indispensable to conduct joint projects, which helps the students learn to manage interpersonal conflicts.

Participating in school managing. The school museum project is linked to the institution as it counts with resources, such as rooms, laboratories, etc..

Involving parents in the learning process. After a period of construction, when the museum has its collection ready for display, the school community in general is invited for visitations, involving the family in school activities.

Applying new technologies for activities. In the begging of researches, the students used books, as well as computer labs. And, to make presentations and formal and informal conferences designed to evaluate them, they had access to projectors and other virtual media.

Facing the obligations and ethical dilemmas of the profession. Reflecting and acting ethically are skills that are consolidated starting from 5thcompetence, because the sense of solidarity is developed with teamwork, preventing the appearance of prejudice and stigmatization.

Carrying out your own continued training. Due to the interdisciplinary nature of the educational museum, projects may culminate in collaboration with other teachers.

During the educational museum installation, the main project started by listing the research problems by group (15 groups of three students). They initiated a project in itself to seek information about the topic under study in order to build their knowledge. At first, the quest was theoretical, and students consulted books, documentaries, newspapers, journals, and specific websites for relevant information on the subject under study. 
Later, the students, with teacher guidance, began to design experiments (laboratory experiments, ethnographies, interviews, visits to archives and newspapers, etc.) or empirical displays (scale models, dioramas, videos, clips, and performances), since, as Hume (2013) said that abstractions and theories are more complex perceptions, from experiences and observations about the phenomena experienced.

In this phase, the experiments were not only demonstrations, but opportunities for students to produce scientific models - such as a group that created a functional model of the Large Hadron Collider of the European Organization for Nuclear Research (LHC-CERN); empirical data collection—questionnaires to understand the perceptions of students about homophobia in schools; building models of constructions of Ancient Egypt and interviews with professionals from the areas of interest of the projects. The students, aside from developing a theoretical framework, built an empirical "corpus" for each research. The museum themes were composed by other student researches as an aquarium with alive aquatic plants and reproducing fishes (Guppy—Poeciliareticulata), Leonardo da Vinci’s flying machine models, a wall-painting picturing marine biodiversity and the specific sea zones, a solar system diorama in the ceiling, trilobites, ammonites and reptile fossils, and model of fossilized plants and dinosaurs, three dimension puzzles of the human body vital organs, forensic biology dioramas, a diorama with clay and plaster models of the extinct biodiversity found in Burgess Shale and posters with researches about eye color, studies about Human Immunodeficiency Virus (HIV) molecular mechanisms and Acquired Immune Deficiency Syndrome (AIDS) prevention, studies about history of wine.

As the project progressed, the teacher has promoted field trips with specific groups of students or with all students, as for an example, visiting an oceanographic museum and a museum of science and technology. In addition to the field trips, they had conversations with professionals working in the formal reconstruction of knowledge, as oceanographers, a paleontologist, an immunologist, a psychologist, a game designers, historians, philosophers, journalists, mathematician, and others, most of them with doctorates in their fields.

Thereafter, the students began to systematize the ideas investigated by developing a poster $(90 \mathrm{~cm} \times 60 \mathrm{~cm})$ of their research. These posters were presented during the II Scientific and Cultural High School Fair, in which students' research has been presented and evaluated by professionals of different areas, most of them with doctorates in their fields as well. After this fair, the students' models, dioramas, and posters were converged and organized in the classroom they used to have biology classes.

The "Science and Consciousness Museum" was understood a tangible and intangible space where the students' research work occurs. It surmounted the materiality for being a freedom of action area and inciting of the students' thoughts. Due to the particularities that working with an investigative approach to curriculum requires, the space was organized to encourage student learning and interpersonal relationships. It consists in the environment that aimed to allow students to take a protagonist role in building their own learning.

It stands out as well, that was not a static space, but in a continuous process of change and (re)modeling by the students to come, ensuring that the research and models built by students integrate the museum's collections.

\section{Final Remarks}

Throughout this research, it is sought to show how the framing of a educational museum represent an innovation, seeing as it breaks with logocentric and "common sense" educational practices, in which the teachers are supposed to be the center of the teaching process. In proposing a new learning environment, it is 
also changed the approach and the teaching strategy used, with the adhibition of research standing out as an pedagogical principle. Thus, promoting a science teaching that aims to nurture critical and complex thinking.

Once encountering innovative practices that hold their ground, even with the pressures from a traditional education system — which is still present in Brazilian education, either through content-based classes or in evaluations based on tests and exams-it is usual to detect these practices in the school context. However, as may be seen in this research, didactic innovation requires, above all, a conceptual change in the teachers themselves, in which they verbalize and notice the concepts of "student," "learning," "teaching," and in the case of science education, the conceptions of science that remain implicit in their practices (Fullan, 2002; Becker, 2004; García, 2011). It is also relevant to remark the key importance of the participant teacher reflexing about his autobiography, relating childhood and youth to his ways of establishing his own "praxis."

Therefore, the practical innovation developed lies in severing an existing asymmetric perception between school knowledge and everyday knowledge, and overcoming a posture where the teacher is considered "wiser" than the student, i.e., dematerializing a vertical perspective of the teacher-student relationship, making it be permeated by responsive ethics. Similarly, a practice that conceives the student as the protagonist in his or her own learning, makes learning itself come to be seen as a subjective construction, in which the teacher occupies a co-participant function.

Nevertheless, the investigated practice should not be taken as a prescription to be followed by other institutions or professionals. As it has tried to phrase, the phenomenon analyzed achievements are closely related to the biography of the teacher who carried it out, with references that he contacted during the study period and that was born from the social and educational context in which it operates.

It is possible that other teachers may wage similar pedagogical approaches-didactic innovations-inspired on the studied phenomenon. It is stressed, however, that repeating it without a critical analysis of the reality in which it will be inserted and without carrying out a thorough investigation of the specific school's needs of changing, it could lead to an vacuous activity. This experienced may be followed-if desired —in its pedagogical approach, but never as a recipe. In short, this is not an experience to follow-those who follow may obey and do not question. It is an experience to be deconstructed, analyzed, and used as speculative material for a critical reflection and a reworked summary of what is made in a thoughtless way — teaching common sense-and what should be (re)done in every classroom, destroying oppressive and neglecting homogenizing instruments. Remembering the urgency of aiding students to be thinking citizens, with "dreaming power" and "constructive volition." Considering reality is an individual construct, intangible and unique to each person. Who is this challenge good for?

\section{Conclusion}

Concluding may not be achievable in a research of this nature. As human beings are never finished, the educational process is a non-ending dynamic. However, after setting and analyzing this data, it is possible to spin thoughts about a reality experienced by a teacher "in the trench" of a public school located in a peripheral region, dealing with people struggling to live with dignity (knowledge, health, and political empowerment). It may be said that the teacher, carrying his/her world views and competences, could interact with students showing different perspectives of life and offering ways of learning and building knowledge with joy and yoked to social reality. Hence, the students could transform their realities and understand other facets of nature. Teaching science is not more important than teaching to think. Science, as well, is not more than a limited way 
to understanding nature. Therefore, contents, experiments, school researches, museums, and science fairs are only tools to develop a real "Didactic Innovation": enabling students to be their own teachers. Henceforth, protagonists of their understanding, being empowered to contribute to their communities.

In the small environment in which the research was developed, we suggest that the teacher attempt to "innovate," by framing an educational museum by the students inquiries and wishes was a feasible instrument to promote different ways of thinking and allowing people to create based on their aspirations. The participant teacher's patent neglect towards the school common sense: Content that must only be recited, copied, and memorized — was a keen element of the "Museum of Science and Consciousness," once the focus of his/her praxis and pedagogical approach was the students and their learning distinct ways and needs. We finish this text quoting the partipant teacher: "People are far more important than contents. Only in an enjoyable environment, of well-being and freedom of thought it is possible to learn and create, ergo, being more than a student: being an author.”

\section{References}

Astolfi, J. P., \& Delevay, M. A. (2005). Didática das ciências (The didactic of sciences) (9th ed.). Campinas, S.P.: Papirus. Bachelard, G. A. (1996). Formação do espírito científico (The formation of the scientific spirit). São Paulo: Contraponto.

Barcellos, G. B. (2009). Museu da natureza: Um espaço de divulgação da Ciência em uma escola de ensino fundamental e médio (Museum of nature: A space for spreading science in a primary and secondary school). In R. M. R. Borges, V. M. R. Lima, \& A. L. Imhoff. (Eds.). Contribuições de um museu interativo à educação em ciências e matemática (Contributions of an interactive museum to the education in science and mathematics). Porto Alegre: EDIPUCRS.

Barcellos, G. B. (2012). O papel de um museu de ciências construído por alunos de ensino fundamental na divulgação científica (The role of a science museum built by primary school students in divulging science) (Master thesis, Pontifícia Universidade Católica do Rio Grande do Sul, Programa de Pós-Graduação em Ciências e Matemática, Porto Alegre).

Barcellos, G. B. (2013). Manual de implantação de museus escolares (Implantation manual of educational museums). Porto Alegre: EDIPUCRS.

Becker, F. (2004). A epistemologia do professor (The epistemology of the teacher) (11th ed.). Petrópolis: Vozes.

Berger, P., \& Luckmann, T. (1985). A construção social da realidade: Tratado de sociologia do conhecimento (The social construction of reality: Sociology of knowledge treaty). Petrópolis: Vozes.

Bizzo, N. (2013). História da ciência e ensino da ciência: Instrumentos para a prática e a pesquisa escolar (History of science and science education: Tools for practical and scholarly research). In V. A. Arantes (Ed.), Ensino de ciências: Pontos e contrapontos. São Paulo: Summus.

Bogdan, R. C., \& Biklen, S. K. (1994). A investigação qualitativa em educação (Qualitative research in education). Porto/Portugal: Porto Editora.

Borda, O. F. (1984). Aspectos teóricos da pesquisa participante: Considerações sobre o significado e o papel da ciência na participação popular (Theoretical aspects of participatory research: Considerations on the meaning and role of science in popular participation). In C. R. Brandão (Ed.), Pesquisa-participante (pp. 42-62) (4th ed.). São Paulo: Ed. Brasiliense.

Borges, M. R. R. (1996). Em debate: Cientificidade e educação em ciências (At issue: Epistemology and science education). Porto Alegre: SE/CECIRS.

Borges, R. M. R., Lima, V. M. R., \& Imhoff, A. L. (2009). Contribuições de um museum interativoparaa educaçãoem ciências e matemática (Contributions of an interactive museum education for science and math education). Porto Alegre: EDIPUCRS.

Brasil. (1996). Lei de diretrizes e bases da educação nacional: $n^{\circ}$ 9394/96 (Law of directives and bases of national education: $\mathrm{n}^{\circ}$ 9394/96). Brasília.

Brazil. (2009). Constituição Federal da República Federativa do Brasil (Federal constitution of the Federative Republic of Brazil). São Paulo: Autêntica.

Canário, R. (2006). A escola tem futuro? Das promessas às incertezas (Does school have a future? From promises to uncertainties). Porto Alegre: Artmed.

Chalmers, A. F. (1994). A Fabricação da ciência (The making of science). São Paulo: Fundação Editora da UNESP. 
Chassot, A. (2004). A ciência através dos tempos (Science through the ages). São Paulo: Moderna.

Chassot, A. (2014). Alfabetização científica: Questões e desafios para a educação (Scientific literacy: Questions and challeges for education). Ijuí/RS: Editora UNIJUÍ.

Comenius, J. (2002). Didática Magna (Didactica Magna). São Paulo: Martins Fontes.

Delizoicov, D. Angotti, J. A., \& Pernambuco, M. M. (2011). Ensino de ciências: Fundamentos e métodos (Science education: Rationale and methods). São Paulo: Cortez.

Fernández, I. et al.. (2002). Visiones deformadas de la ciencia transmitida por la enseñanza (Warped visions of science transmitted through teaching). Enseñanza de lasciencia, 20(3), 477-488.

Freire, P. (1981). Educação como prática de liberdade (Education as a practice of freedom) (12th ed.). Rio de Janeiro: Ed. Paz e Terra.

Freire, P. (2011). Pedagogia do oprimido (Pedagogy of the oppressed). São Paulo: Paz e Terra.

Fullan, M. (2002). El significado del cambio educativo: Un cuarto de siglo de aprendizaje. Profesorado (The meaning of educational exchange: Uncuarto de sigloaprendizaje. Teaching staff). Revista de currículum y formación del profesorado (pp. 1-14).

García, C. M. (2011). La profesión docente en momentos de cambios. ¿Qué nos dicen los estudios internacionales? (The teaching profession in times of change. What do international studies say?) (pp. 49-68). CEE Participación Educativa.

Garden H. (2001). A nova ciência da mente (The new science of mind). São Paulo: Editora da Universidade de São Paulo.

Gauthier, C. et al.. (2013). Porumateoria da pedagogia (For a pedagogy of theory: Contemporary research on teaching knowledge) (3rd ed.). Ijuí: Ed. Unijuí.

Gil Pérez, D. (2001). Para uma imagem não deformada do trabalho científico (For a non-distorted image of scientific work). Ciência \& Educação, 7(2), 125-153.

Granger, G. G. (1994). A ciência e as ciências (Science and the sciences). São Paulo: Editora da Universidade Estadual Paulista.

Hanson, N. R. (1975). Observação e interpretação (Observation and interpretation). In S. Morgenbesser. (Ed.), Filosofia da ciência. São Paulo: Cultrix.

Hume, D. (2013). Investigação sobre o entendimento humano (Research on human understanding). São Paulo: Editora Escala.

Kuhn, T. S. (2001). A estrutura das revoluções científicas (The structure of scientific revolutions). São Paulo: Editora Perspectiva.

Moraes, R., \& Galiazzi, M. do C. (2011). Análise textual discursiva (Textual discourse analysis) (2nd ed.). Ver.-Ijuí: Ed. Unijuí.

Moreira, A. F. B. (1998). Didática e currículo: Questionando fronteiras (Teaching and curriculum: Questioning borders). In M. R. N. Santos. (Ed.), Confluências e divergências entre didática e currículo (Confluences and divergences between teaching and curriculum) (pp.7-32). Campinas: Papirus.

Novak, J. D. (1981). Uma teoria de educação (A theory of education). São Paulo: Pioneira.

Ohlweiler, M. I. (2012). A pesquisa como prática curricular ou o currículo como prática investigativa (Research as a curricular practice or the curriculum as research practice). In A. V. Munhoz. (Org.). Diálogos na pedagogia: coletâneas (Vol. 1, 73-90). Lajeado: Ed. Univates.

Perrenoud, P. (2000). Dez novas competências para ensinar (Ten new skills to be taught). Porto Alegre: Artes Médis.

Popper, K. (1972). A lógica da pesquisa científica (The logic of scientific research). São Paulo: Cultrix.

Pretto, N. de L. A. (1995). Ciência nos livros didáticos (Science in textbooks). Campinas, S.P.: Editora da UNICAMP.

Santos, B. de S. (2013). A crítica da razãoindolente (The critique of the lazy reason: Against the waste of experience) (8th ed.). São Paulo: Cortez.

Serres, M. (2013). Polegarzinha. Rio de Janeiro: Bertrand Brasil.

Tardif, M. (2012). Saberesdocentes e formação profissional (Professional knowledge of teachers and training) (13th ed.). Petrópolis, R.J.: Vozes.

Vygotsky, L. (1984). Psicologia pedagógica (Pedagogic psychology). São Paulo: Martins Fontes.

Vygotsky, L. (1987). Formação social da mente (Social formation of the mnd). São Paulo: Martins Fontes. 